\title{
Black Pete, King Balthasar, and the New Orleans Zulus: Can Black Make-Up Traditions Ever Be Justified?
}

\author{
Bouke De Vries ${ }^{1}$ \\ Department of Historical, Philosophical and Religious Studies Umeå University; \\ bouke.devries@umu.se
}

Submitted: 21 October 2020, accepted: 25 March 2021, published: 25 April 2021

\begin{abstract}
Wearing black make-up to impersonate black individuals has become highly controversial in many countries, even when it is part of long-standing cultural traditions. Prominent examples of such traditions include Saint Nicolas celebrations in the Netherlands (which feature a black character known as "Black Pete" who hands out candy to children), Epiphany parades in Spain (which feature impersonations of the biblical king Balthasar who is traditionally portrayed as black) and the annual Zulu parade in New Orleans (which features impersonations of South African Zulu warriors). In this article, I challenge the widely held view that black make-up traditions are categorically wrong. Specifically, I argue that these traditions can be morally vindicated if (i) the large majority of individuals who help to maintain them do not believe that they denigrate black people; (ii) the relevant traditions do not depict black people in denigrating ways; and (iii) the relevant traditions are not gratuitously offensive. While the Dutch Saint Nicholas tradition fails to satisfy these conditions, the New Orleans Zulu tradition is found to satisfy them, as is the Spanish Epiphany tradition in certain cases. I end by identifying another set of conditions under which black make-up traditions might be morally justified.
\end{abstract}

Keywords: Black Pete; King Balthasar; Zulu parade; black make-up traditions; blackface; offence

How to cite: De Vries, B. Black Pete, King Balthasar, and the New Orleans Zulus: Can Black Make-Up Traditions Ever Be Justified?. Journal of Controversial Ideas 2021, 1(1), 8; doi:10.35995/jci01010008.

\footnotetext{
As a young untenured scholar, I am proud to be contributing to this issue. I believe that the history of this article shows the need for this type of journal. The current paper was initially under review at a well-known journal in moral and political philosophy. After the first round of comments, for which the editor of said journal had been able to find only one reviewer, (s)he wrote to me that (s)he was "keen to publish the paper" based on the reviewer's judgement that it was "an interesting paper on a very worthwhile topic" that offered 'plausible theoretical theses' and that was "heading in the direction of being a publishable piece". However, once I had submitted my revisions, which occurred after the start of the BLM-protests (which may or may not have had an impact on the subsequent events), the reviewer declined to review my revisions and the editor not only rejected the paper without revisions based on (what I thought was) a highly biased report by a new reviewer, but also told me that I "might want to reconsider trying to publish the paper" because of the "very real risk of causing unnecessary offence".
} 
(C) 2021 Copyright by the author. This article is an open access article distributed under the terms and conditions of the Creative Commons Attribution (CC BY 4.0) license.

\section{A Tale of Three Black Make-Up Traditions}

The history of black minstrelsy shows in the United States ${ }^{2}$ and Canada ${ }^{3}$ is an ugly one. During the late 19th and early 20th century, it was common for predominantly white actors in the US and Canada to perform as caricatures of black people on stage. With their faces darkened with burnt cork, greasepaint, or shoe polish, they would depict this group as buffoonish and dim-witted in order to entertain their audiences. Part of this tradition's legacy is that the use of black make-up has become highly controversial within North America and increasingly within other parts of the world as well (this is true especially, but as we will see not exclusively, when it is white people who darken their skin).

The past decade has witnessed numerous black make-up scandals. Many of these involved politicians and celebrities who had painted their skin as part of costumes for Halloween, Purim, or themed parties. One might think of American actress Julianne Hough, who impersonated the black character Crazy Eyes from the Netflix series "Orange is the New Black" in 2013, as well as of French footballer Antoine Griezmann, who dressed up as an Afro-American basketball player in 2017. In other cases, the scandals involved the publication of pictures that showed high-profile individuals wearing black make-up in earlier decades. For example, in 2019, Virginia Governor Ralph Northam admitted to featuring in a medical school yearbook photo that showed one person in Ku Klux Klan robes and one person in black face paint, a confession he subsequently withdrew only to confess instead that he had painted his face with shoe polish in the 1980s as part of a Michael Jackson dancing contest. ${ }^{4}$ Later that year, Canadian Prime Minister Justin Trudeau was confronted with photos that showed him wearing black make-up on different occasions during the 1990s and early 2000s, which included a photo of him dressed as Aladdin at a gala. ${ }^{5}$

I discuss these cases in other work where I consider whether darkening one's skin as part of a personal costume is ever morally defensible. ${ }^{6}$ My aim here is to consider whether doing so can ever be justified as part of a cultural tradition, which is a question that has not received any attention from philosophers. As the following examples illustrate, such traditions have sparked, and continue to spark, considerable controversy as well.

Black Pete: In August 2015, the United Nations Committee on the Elimination of Racial Discrimination released a report in which it urged the Netherlands to get rid of the figure of Black Pete [Zwarte Piet], who is often played by white people who darken

2 Stephen Johnson, ed., Burnt Cork: Traditions and Legacies of Blackface Minstrelsy, First edition (Amherst ; Boston: University of Massachusetts Press, 2012).

3 Robin W. Winks and Robin William Winks, The Blacks in Canada: A History (Montreal: McGill-Queen's Press, 1997), 294.

4 Dan Merica and Ryan Nobles, "Northam Denies Being in Racist Photo but Recalls Darkening His Skin in Michael Jackson Dance Contest in 1984," CNN, March 2, 2019, https://www.cnn.com/2019/02/02/politics/ northam-racist-yearbook-photo/index.html.

5 BBC, "New Video of Trudeau Wearing Blackface Emerges, " BBC News, September 19, 2019, sec. US Canada, https://www.bbc.com/news/world-us-canada-49758613.

6 See De Vries, B. Why shouldn't race be a costume? A qualified defense of cross-racial face paint (Manuscript). 
their skin and wear Afro-wigs. Black Pete is an assistant of Saint Nicolas, a Catholic saint who arrives in Dutch, Belgian, and Antillean towns in late November in order to bring candy and presents to children. While there is ample evidence that Pete was intended to represent a black servant when he became part of Saint Nicholas celebrations during the 19 th century, ${ }^{7}$ the dominant narrative has become that his black complexion is due to him going up and down chimneys in order to deliver candy and presents inside children's homes. ${ }^{8}$ In the eyes of the UN committee, however, he remains a morally unacceptable character, ${ }^{9}$ a view that is shared by a growing minority of Dutch people, as well as by the municipal governments of cities such as Amsterdam and Rotterdam that have replaced their Black Petes for white Petes with soot smudges on their faces [so-called Roetveeg Pieten] in recent years. ${ }^{10}$

King Balthasar: In January 2019, Spanish footballer Andres Iniesta sparked an outcry on social media after he had posted a picture of himself and two friends whose faces were painted black for Epiphany celebrations. The two friends were representing the biblical king Balthasar and his page, who are traditionally depicted as black in Spain and who are often impersonated by white people. Commenting on the incident, BBC radio and television presenter Nick Bright said, "I cannot believe that in 2019, famous people are still doing or are around people doing 'blackface' and tweeting it", whereas journalist and author Musa Okwonga wrote, "I just wonder how you can share a dressing room and so many trophies with Eric Abidal and Dani Alves [two black footballers] and still not realise this is not cool [ ... ] it's very disappointing". ${ }^{11}$ However, it is not just people from outside of Spain who have been critical of white individuals darkening their skin as part of Balthasar impersonations. In various Spanish cities, petitions for giving black individuals the exclusive right to play Balthasar in Epiphany parades have been launched in recent years, ${ }^{12}$ a wish that some municipalities_-including the city of Madrid—have accommodated since. ${ }^{13}$

7 More on this in the next section.

8 Lisette Van Vliet and Jeroen Kester, "Onderzoek: Uiterlijk van Zwarte Piet," 1V Opiniepanel Rapport (Hilversum: Een Vandaag, November 15, 2018).

9 Somini Sengupta, "U.N. Urges the Netherlands to Stop Portrayals of 'Black Pete' Character," The New York Times, December 21, 2017, sec. World, https://www.nytimes.com/2015/08/29/world/europe/zwartepiet-netherlands-united-nations.html.

10 RTL Nieuws, “Vanaf volgend jaar alleen nog roetveegpieten bij intocht Rotterdam," RTL Nieuws, November 21, 2018, https://www.rtlnieuws.nl/nieuws/nederland/artikel/4493176/vanaf-volgend-jaaralleen-nog-roetveegpieten-bij-intocht-rotterdam.

11 BBC, "Andres Iniesta: Former Barcelona Midfielder Criticised for Posing with Two People in Blackface," January 7, 2019, sec. European Football, https://www.bbc.com/sport/football/46780520. A similar fate befell former Real Madrid and Malaga player Ruud van Nistelrooy a few years earlier. In 2013, the Dutch striker had dressed up as Balthasar to bring presents to hospital staff and patients in Marbella, which led some Twitter users to ask, "What the sweet Jesus is Ruud Van Nistelrooy doing?", with others calling him "A Huge Racist Piece of Shit". See Jill Reilly, "Ruud Van Nistelrooy Sparks Racism Row after 'blacking up' for Three Kings Day as He Visits Children in Spanish Hospital," Mail Online, January 7, 2013, https://www.dailymail.co.uk/news/article-2258329/Ruud-Van-Nistelrooysparks-racism-row-blacking-Three-Kings-Day-visits-children-hospital.html.

12 Lalnformacion, "No tiene sentido que el rey Baltasar en nuestra cabalgata sea un señor blanco pintado de negro," La Información, December 30, 2013, https://www.lainformacion.com/asuntos-sociales/ no-tiene-sentido-que-el-rey-baltasar-en-nuestra-cabalgata-sea-un-senor-blanco-pintado-de-negro_ ydjtSLisY0DGleTgG4nr45/.

13 Esther Sánchez and El País, "After Years of Pressure, Madrid's King Balthazar to Be Played by Black Man," El País, September 18, 2015, sec. Inenglish, https://elpais.com/elpais/2015/09/17/inenglish/ 1442504152_142507.html. 
The New Orleans Zulus: In February 2019, the Zulu Social Aid and Pleasure Club of New Orleans responded to the growing condemnation of its 115-year-old Zulu parade, which takes place during the city's Mardi Gras carnival. Every year, approximately 1500 of its members darken their face (of whom about $80 \%$ are black and $20 \%$ white) in order to represent the South African Zulu worriers who managed to expel the British colonists from their land in $1879 .{ }^{14}$ In the media report that was issued, the club wrote that its "black make-up is NOT the same as black-face", before adding that its "history [which involves providing financial and social support to poor African Americans] makes it abundantly clear that nothing about the organization, including the black make-up, was ever intended to insult or degrade African Americans" but that, "to the contrary, Zulu has always been about celebrating African and African American culture, strength, and pride". ${ }^{15}$ Many Americans remain unconvinced, however, and even within New Orleans itself, the Zulu parade has its opponents. Just witness recent comments by a spokesperson of an anti-Confederate statues campaign within the city, who said that "they [the members of the Zulu Social Aid and Pleasure Club] know good and damn well that this blackface has its roots in minstrelsy and that they are the modern-day minstrels". ${ }^{16}$

While black make-up traditions (i.e., cultural traditions in which black make-up is used) are highly controversial, then, the remainder of this article challenges the widespread view that they are categorically wrong. Specifically, it argues that such traditions can be morally vindicated if (i) the large majority of individuals who help to maintain these traditions do not believe that they denigrate black people; (ii) the relevant traditions do not depict black people in denigrating ways; and (iii) the relevant traditions are not gratuitously offensive. Whereas the Dutch Saint Nicholas tradition fails to satisfy these conditions, the New Orleans Zulu tradition is found to satisfy them, as is the Spanish Epiphany tradition in certain cases. I end by identifying another set of conditions under which black make-up traditions might be morally justified.

\section{When Black Make-Up Traditions Are Morally Justified}

Let us look in greater detail at the three conditions that I believe are jointly sufficient for rendering black make-up traditions morally defensible.

\section{Immoral vs. Innocent Attitudes}

The first condition is that the large majority of individuals who help to maintain black make-up traditions, whether by participating in their respective events or by helping to organise these events, do not believe that their local black make-up tradition denigrates black people. This condition is predicated on the assumption that the moral character of black make-up traditions is tainted when those responsible for their continued existence

14 John Simerman, "Zulu Statement on 'blackface' Controversy: 'Black Makeup Is NOT the Same'; Club Defends Its History," NOLA.com, February 13, 2019, https://www.nola.com/entertainment_life/mardi_ gras/article_b45f04c8-b1aa-507f-805f-08618d093802.html.

15 Zulu Social Aid and Please Club Inc., "Black Makeup Is NOT the Same as 'blackface," Facebook, February 14, 2019, https://www.facebook.com/ZuluSAP1909/posts/2218617234856752.

16 John Simerman, “For Zulu Leaders, Blackface Remains 'Tradition,' 'cultural Expression' Even amid National Reckoning," The Advocate, December 2, 2019, https://www.theadvocate.com/new_orleans/ news/article_d8b7049a-2f16-11e9-832c-4311bec00c93.html. 
think that these traditions are demeaning to black people, as this means that said traditions will be kept alive by individuals who believe that black people are denigrated by their local black make-up tradition and who:

I. support the tradition for that very reason; or who

II. are indifferent to the perceived denigration; or who

III. regret the perceived denigration, but tolerate it as collateral damage.

Cases where black make-up traditions are maintained in order to denigrate black people (I) are clearly the most problematic from a moral perspective as they involve an endorsement of hostility towards a particular racialized group (which according to the influential volitional account of racism proposed by Jorge Garcia is sufficient to classify them as racist $)^{17}$. However, there is also a failure to show due concern to black people when those responsible for sustaining black make-up traditions believe that these traditions denigrate black people but are simply indifferent to this (II). To see this, notice that, although there is no endorsement of hostility in such cases, the relevant agents still fail to acknowledge black people as individuals whose interests count morally. ${ }^{18}$ Indeed, even when such perceived denigration is regretted but tolerated as collateral damage (III), moral principles are being flouted. The reason for this is that respect for other people's humanity is not something that can be permissibly traded off against other goods; instead, it ought be observed in every possible situation, which is a view that is central to many moral doctrines, including Kantian and Christian ones.

To be sure, when only small percentages of those responsible for maintaining black make-up traditions satisfy (I), (II), or (III), this does not seem to impugn the moral character of these traditions as a whole. If such small minorities had such power, then even traditions with the most laudable objectives would be morally unjustified when, and because, a tiny fraction of their participants and organisers had dubious motives for participating in them or for assisting in their organisation. For example, it would mean that an annual company charity run must be morally unjustified when, and because, a mere one percent of employees do not take part in this event to contribute to a good cause or to socialise with colleagues, but rather to derive sadistic pleasure from seeing a disliked colleague be lapped by fellow workers. Another implausible implication of setting the justificatory bar this high is that it renders it doubtful as to whether any morally defensible cultural traditions would remain. This is because, as a matter of statistical probability, any tradition with a reasonably large number of participants and organisers is likely to have some individuals whose participation or organisational contributions are driven by depraved motives. For example, in cities with public Christmas trees and nativity scenes, there might be some volunteers who help to set up these trees and scenes not so much because they want to spread the holiday spirit, but rather because they value the public display of Christian symbols as a way of signalling the supposed superiority of Christians over members of other religions.

17 J. L. A. Garcia, "The Heart of Racism," Journal of Social Philosophy 27, no. 1 (1996): 5-46, doi:10.1111/j.1467-9833.1996.tb00225.x.

18 Reflecting the seriousness of such neglect, Garcia's moralised conception of racism (on which racism is always and necessarily wrong) encompasses cases where there is "racially based or racially informed disregard", which is defined as "an indifference [... ] to another's welfare on account of the racial group to which she is assigned". See Garcia, J. L. A., "Three Sites for Racism: Social Structures, Valuings, and Vice.," in Racism in Mind, ed. Michael P. Levine and Tamas Pataki (Ithaca, N.Y: Cornell University Press, 2004), 43. 
By contrast, when almost all of those responsible for maintaining a given black make-up tradition satisfy (I), (II) or (III), this does appear enough to render the tradition morally unjustified. To deny this would have odd implications as well. For example, it would mean that for a mere $1 \%$ of these individuals to believe that the relevant tradition does not denigrate black people might compensate for the $99 \%$ who believe that it does and who are willing, and possibly more than willing, to tolerate this with all the disrespect that comes with such toleration (see my comments in the penultimate paragraph). However, if these observations are correct, then somewhere in between these extremes there exists a point where precisely enough participants and organisers of a black make-up tradition satisfy (I), (II), or (III) in order to render the tradition morally unjustified. Although it is difficult, if not impossible, to pinpoint this percentage, my sense is that roughly $20-30 \%$ is needed.

What is pertinent for us is that the black make-up traditions examined in this article all seem to fall short of this threshold. This is perhaps most obvious as far as the New Orleans Zulu parade is concerned; given the United States' history of slavery and Jim Crowe segregation, it is highly unlikely that the black members of the Zulu Social Aid and Pleasure Club would use black make-up if they thought that this mocked their own race, let alone that they would encourage white paraders to do so. In addition to such abductive evidence, there exist large amounts of testimonial evidence that few, if any, of them believe that their parade involves such mockery. For instance, Jay Banks, a onetime Zulu king who is currently chairman of the club's board of directors, notes that "Blackface is pretending that black people are less than human; the black make-up that we wear has nothing to do with that", ${ }^{19}$ which is a view that is echoed in the already quoted statement by the Zulu Club in which it was said that "nothing about the organization, including the black make-up, was ever intended to insult or degrade African Americans" but that, "to the contrary, Zulu has always been about celebrating African and African American culture". ${ }^{20}$

Turning to the role of Black Pete in Dutch Saint Nicholas celebrations-call this the "Black Pete tradition" for short-I have mentioned already that the dominant narrative concerning Pete's blackness is that he is covered in soot as a result of going up and down chimneys in order to deliver candy and presents inside children's homes. The widespread acceptance of this narrative is mirrored in a representative national poll from 2018 in which $80 \%$ of respondents reported that they did not consider Black Pete to be a "racist phenomenon". ${ }^{21}$ When we focus exclusively upon the proponents of the Black Pete tradition, this percentage is likely to be higher still.

Now, those who believe that Black Pete portrays black people in a denigrating manner might retort that, deep down, most of his supporters know that this figure is offensive towards black people but are unwilling to admit this as this would require them to acknowledge that they are supporting a racist practice, which is something that is taboo within the Netherlands. My reply to this is that, while the claim about how black people are portrayed by Black Pete is correct (more on this in the next subsection), it is doubtful whether most Black Pete supporters, or even simply a large minority of them, actually perceive this character to be denigrating towards black people. The main evidence for

19 Michelle Krupa CNN, "The Black Leaders of an Iconic Mardi Gras Parade Want You to Know Their "Black Makeup Is NOT Blackface, "' CNN, May 3, 2019, https://www.cnn.com/2019/02/16/us/zulu-new-orleansblackface/index.html.

20 Clarence Becknell, Thomas Price, and Don Short, "History Of the Zulu Social Aid Pleasure Club," accessed June 4, 2019, http://www.kreweofzulu.com/history.

21 Van Vliet and Kester, "Onderzoek: Uiterlijk van Zwarte Piet." 
thinking otherwise comes from a 2016 study among 207 Dutch children aged 5-7. In this study, which used a combination of open-ended questions and labelling exercises, it was found that, although the participating children "are clearly aware of Black Pete's skin color and subordinate status", they associate Black Pete "more with clowns than with black people". ${ }^{22}$ According to the researchers, these findings provide good reasons for thinking that, like the children in this study, current Dutch adults have from early childhood onwards experienced Black Pete as "reminiscent of a clown rather than a real black person", which causes them to see this character as nonracist. ${ }^{23}$ (For what it is worth, this hypothesis is consistent with my own childhood experiences; as a 13 year old, I was utterly perplexed when a friend of mine suggested to me that the Saint Nicholas tradition is racist, ${ }^{24}$ and even after he had made the link between Black Petes and black servants, I thought that this was a far-fetched and, indeed, perverse, interpretation of the tradition.) Further reasons for thinking that Black Pete supporters are generally sincere when they report that they do not perceive Black Pete to be racially offensive are provided by the widespread support that this character continues to enjoy on the Dutch-Caribbean island of Bonaire where the population is predominantly black and where Pete impersonators are in fact painted much darker than their European-Dutch counterparts (more on this in Section 4). The thought here is that, if it were very difficult, if not impossible, to see Black Pete as nonracist, one would expect Black Pete to be highly controversial among Bonaireans given that, for the large majority of them, it is their racialized group that is being ridiculed by this character.

Turning finally to the role of Balthasar in Spanish Epiphany parades-call this the "Balthasar tradition" for short-what we see is that, within various Spanish municipalities where Balthasar continues to be played by white individuals, the organisers of these parades have emphatically denied that this practice is disrespectful towards black people. ${ }^{25}$ While it cannot be entirely ruled out in this case either that these denials merely reflect a desire not to be thought of as a racist, there is a nonsceptical explanation for them that seems more plausible. Whereas the blackness of Balthasar's skin can be explained by the fact that he is popularly known as a black African king within Spain and various other countries, ${ }^{26}$ the fact that he is often played by white individuals in Epiphany parades can be explained by the custom of many Spanish municipalities to let local councillors perform this role who, mirroring Spain's demography, tend to be relatively light-skinned. (This rationale was invoked by, e.g., Ana Botella, former leader of Madrid's city council, before the city of Madrid decided in 2015 to reserve the role of Balthasar for black people; as she put it at the time, "if there was a black councilor, then we would have a black king".) ${ }^{27}$

22 Judi Mesman, Sofie Janssen, and Lenny van Rosmalen, "Black Pete through the Eyes of Dutch Children," PLoS ONE 11, no. 6 (June 20, 2016): e0157511, doi:10.1371/journal.pone.0157511.

23 Mesman, Janssen, and Rosmalen.

24 Notice that this was before the debate about Black Pete became a national discussion.

25 Alan Ruiz Terol, "Blackface at Epiphany Parade Sparks Outrage," CatalanNews, October 1, 2018, http://www.catalannews.com/society-science/item/blackface-at-epiphany-parade-sparks-outrage.

26 Accordingly, there are examples of people wearing black make-up to represent Balthasar in countries such as Austria and Germany. See The Local, "Three Kings Bring Epiphany to Austria," The Local, January 6, 2015, https://www.thelocal.at/20150106/three-kings-bring-epiphany-to-austria; Deutsche Die Welle, "Why Children Dress up as the Three Magi in Germany," DW.COM, May 1, 2016, https://www.dw.com/ en/why-children-dress-up-as-the-three-magi-in-germany/a-18957652.

27 Ashifa Kassam, "Madrid Ends Blacking up of Characters in Post-Christmas Tradition," The Guardian, September 17, 2015, sec. World news, https://www.theguardian.com/world/2015/sep/17/madrid-endsblacking-up-post-christmas-tradition. 


\section{Degrading vs. Nondegrading Depictions of Black People}

What I want to suggest next is that, even when those responsible for maintaining specific black make-up traditions do not believe that black people are being denigrated by their local black make-up tradition, such traditions remain morally problematic when they portray this group in denigrating ways as this fails to respect their members' dignity, apart from any instrumental harms that it might cause. ${ }^{28}$ An analogy might be drawn with a young child giving the finger to a random person. As Joshua Glasgow observes, even when this child does not realise that raising his middle finger to a random person is disrespectful-perhaps he is just imitating a bad habit of his older brother-his doing so remains morally problematic within Western cultures given that it fails to respect the dignity of the person who is being flipped off. ${ }^{29}$ Yet, if having denigrating features is sufficient to render a tradition morally problematic even when no disrespect is intended or even perceived by those responsible for its continued existence, then a second condition that many justifiable black make-up traditions will satisfy, though perhaps not all (more on this in Section 4), is that they do not depict black people in denigrating ways.

Some black make-up traditions fail to satisfy this condition. Consider the Black Pete tradition in the Netherlands. The dominance of the chimney-soot narrative notwithstanding (see the introduction), there are ample cues that Black Pete is representing a black servant and thereby depicting black people in a demeaning manner, which include:

- $\quad$ the fact that he has an afro-wig (one does not grow afro-hair just by going up and down chimneys);

- $\quad$ the fact that he has garish red lips and wears golden hoop earrings (which are attributes of black people on crude stereotypes);

- $\quad$ the fact that he wears a page costume;

- the fact that he became part of the Saint Nicholas tradition during the 19th century, a time when the Dutch were still active participants in colonialism and-for much of the century-slavery, which was not abolished until $1863 .{ }^{30}$

By contrast, both the Spanish Balthasar tradition and the New Orleans Zulu tradition seem to satisfy the current condition. Consider first the Balthasar tradition; unlike the role of a servant, the role of a king is not only not a submissive one, but arguably one with a lot of prestige. This is true especially of the role of a wise king, as the three kings in Epiphany celebrations are also known as the Three Wise Men, a predicate that can be traced to a passage from the book of Matthew in which it is said that, after Jesus' birth, "wise men from the east came to Jerusalem" (Matt. 2:1). Of course, there are ways of portraying Balthasar that are denigrating to black people. Examples of this may be found among cases where Balthasar impersonators make their lips seem unnaturally red and large, or where they act in a dim-witted manner just as blackface actors in North American minstrel shows did.

28 Which may include (reinforced) discrimination against black people and the undermining of their self-respect. How likely it is that these and other possible harmful effects occur is something on which I remain non-committal here. For further discussion, see Marike Lefevre, "Zwart Geschminkte Personages in Tradities Uit Europa-Een Mensenrechtelijke Blik," Ethische Perspectieven 29, no. 4 (2019): 203-19, doi:10.2143/EPN.29.4.3287437.

29 Joshua Glasgow, "Racism as Disrespect," Ethics 120, no. 1 (2009): 83, doi:10.1086/648588.

30 Frits Booy, Het Verhaal van Zwarte Piet (Utrecht: Nederlands Centrum voor Volkscultuur en Immaterieel Erfgoed, 2014). 
What is apposite for us is that this only shows that particular ways of impersonating this character are morally problematic, not that all ways are.

Regarding the New Orleans Zulu parade, it is similarly difficult to see how this tradition would depict black people in a disrespectful manner unless one has already accepted that any use of black make-up is demeaning towards this group, which is what needs to be shown. Similar to the role of a king, the role of a Zulu warrior is not a submissive one. Furthermore, the fact that the New Orleans Zulus have white areas around their mouths and eyes (often around one eye) and wear colourful costumes means that they more closely resemble mythical figures than the black characters of North American minstrel shows to which they are frequently compared. ${ }^{31}$ Another relevant difference between these traditions can be found in their respective origins; whereas minstrel shows were introduced by white people during the $19^{\text {th }}$ century in order to entertain white audiences at the expense of black people, ${ }^{32}$ the Zulu parade was started by a group of black labourers from New Orleans in 1909 after they had attended a theatre-play about the South African Zulu warriors. ${ }^{33}$ In addition to satisfying a desire to pay homage to their African ancestry and to Afro-American culture, ${ }^{34}$ many scholars believe that dressing up as Zulus served subversive purposes within a racially segregated society in which black people were heavily oppressed. For example, according to Joseph Roach, the Zulu impersonations were a way to "make fun of white folks and the stupidity of their jury-rigged construction of race". 35

\section{Gratuitous vs. Nongratuitous Offence}

Thus far, we have looked at two conditions out of a set of three that I submit are jointly sufficient for rendering black make-up traditions morally justified. According to the third and final condition of this set, the use of black make-up is not gratuitously (i.e., unnecessarily) offensive. In my understanding, such gratuitous offence exists if and only if (i) at least some people are offended by the use of black make-up, which here means that they experience certain negative mental states such as shock or anger, and (ii) its use could be abandoned with little loss, if any.

As far as (i) is concerned, it is clear that many places with black make-up traditions are home to individuals who are offended by these traditions. Evidence for this can be found among the campaign against Black Pete by the organisation, Kick Out Zwarte Piet; ${ }^{36}$ the campaign against the use of black make-up in Epiphany parades by the Asociación

31 Compare C. W. Cannon, "Behind the Zulu Blackface Flap: Liberal Guilt, Clueless Outsiders," The Lens, October 4, 2017, https://thelensnola.org/2017/03/10/behind-the-zulu-blackface-flap-liberal-guiltclueless-outsiders/.

32 Stephen Johnson, Burnt Cork: Traditions and Legacies of Blackface Minstrelsy (Univ of Massachusetts Press, 2012).

33 Becknell, Price, and Short, "History Of the Zulu Social Aid Pleasure Club"; Kevin McQueeney, "Zulu: A Transnational History of a New Orleans Mardi Gras Krewe," Safundi 19, no. 2 (April 3, 2018): 142, doi:10.1080/17533171.2018.1407083.

34 Zulu Social Aid and Please Club Inc., "Black Makeup Is NOT the Same as 'blackface."

35 Joseph R. Roach, Cities of the Dead: Circum-Atlantic Performance (Columbia University Press, 1996), 21. For criticism, see McQueeney, "Zulu," 148.

36 Roberts, "Kick Out Zwarte Piet (KOZP)," Stichting Nederland Wordt Beter (blog), accessed August 8, 2020, https://www.nederlandwordtbeter.nl/projecten/zwarte-piet-is-racisme-campagne/kozp/. 
Centro Panafricano; ${ }^{37}$ and the campaign against the New Orleans Zulu parade by the anti-Confederate statues organisation, Take 'Em Down NOLA. ${ }^{38}$ There is also much anecdotal evidence for the existence of such offence. For example, Mitchell Esajas, one of the leading figures in the movement against Black Pete, has referred to the Saint Nicholas period as "one of the worst times to be in Holland because everywhere you go you are faced with this offensive Blackface". ${ }^{39}$ Likewise, Daouda Dieye, a Senegalese street vendor who has lived in Catalonia for 12 years, describes how the use of black make-up by white Balthasar impersonators causes him to feel "angry, sad, and outraged", ${ }^{40}$ whereas Kim Coleman, curator of the New Orleans' McKenna Museum of African American Art, notes how she has stopped attending the New Orleans Zulu parade because she finds the sight of white people wearing black make-up "disgusting". ${ }^{41}$ Many more examples could be given.

What about (ii)? Regarding the Black Pete tradition in the Netherlands, it is sometimes argued that the use of black make-up is superfluous. Such arguments are usually based on two premises-namely, that the Saint Nicholas tradition is, or ought to be, a children's holiday, and that children are indifferent as to what skin colour the Petes have. ${ }^{42}$

Whatever the merits of the first premise, it seems to me that the second premise is false. To see why, notice that Petes at domestic Nicholas celebrations are usually played by relatives or family friends, who will be much easier to recognise for children when their faces are not painted black. For the purposes of this article, however, I do not want to pursue this point further as the fact that Black Pete has racially denigrating features (see the previous subsection) is already enough to show that this character is morally problematic. Instead, I want to use the available space to focus on the New Orleans Zulu tradition and the Spanish Balthasar tradition.

With respect to the New Orleans Zulu tradition, what we find is that wearing black make-up is a central element of this tradition, which means that any offense that it causes cannot be gratuitous. Not only do members of the Zulu Social Aid and Pleasure Club attach great value to this practice, as exemplified by their fierce resistance to outside pressure to abandon it, ${ }^{43}$ their use of black make-up has a long history going back to the beginning of the parade in 1909 when the first Zulu impersonators were too poor to afford masks and instead used paint in order to abide by the city's carnival rules (which required

37 Lalnformacion, "No tiene sentido que el rey Baltasar en nuestra cabalgata sea un señor blanco pintado de negro."

38 Amanda Roberts, "Take ‘Em Down NOLA Protests Krewe of Zulu's Use of Black Makeup," FOX8live, February 21, 2019, https://www.fox8live.com/2019/02/22/take-em-down-nola-protests-krewe-zulus-useblack-makeup/.

39 Melissa Noel, “The Fight Against 'Black Pete', a Holiday Blackface Tradition”, NBC News, December 23, 2015, https://www.nbcnews.com/news/nbcblk/fight-against-black-pete-holiday-blackface-traditionn485081.

40 Terol, "Blackface at Epiphany Parade Sparks Outrage."

41 Richard Fausset, "A Black Group Says Mardi Gras Blackface Honors Tradition. Others Call It 'Disgusting."', The New York Times, February 17, 2019, sec. U.S., https://www.nytimes.com/2019/02/ 14/us/zulu-parade-new-orleans.html.

42 See, e.g., Isa Van Waardenberg, "Draait het Pieten-debat wel echt om de kinderen?," Metronieuws.nl, November 13, 2019, https://www.metronieuws.nl/lezerscolumn///draait-het-pieten-debat-wel-echt-omde-kinderen/.

43 Simerman, 'For Zulu Leaders, Blackface Remains 'Tradition,' 'cultural Expression' Even amid National Reckoning." 
parade participants to hide their identities). ${ }^{44}$ In fact, even the use of black make-up by white parade participants, which is believed to have started in the 1970s, has an important meaning for many members of the Zulu Club who have referred to it as an "exchange of culture" 45 and a "celebration of integration". 46

By contrast, the use of black make-up is not essential to the Balthasar tradition. If it were, then black Balthasar performers too would be expected to use black make-up in the same way that black Zulu paraders are expected to use it, which is not the case. What is essential to a tradition that revolves around three kings, however, is that the kings be easily distinguishable, which suggests that the use of black make-up has an important function when no black Balthasar performers are available. To see this, it should be noted that, unless one of the kings is painted black in such cases, telling them apart can be a challenge, especially from a distance, as the fact that they are all male characters with royal attributes such as crowns and mantles means that there are few other features to differentiate them (the main ones being that Caspar is usually depicted as an old man with a white beard and Melchior as a middle-aged man with a red beard).

Some might reply that efforts could be made to ensure that a nonblack Balthasar looks different from his fellow kings. This may be achieved, for instance, by representing him as the only king without a beard. What is important for us is that, even if this solves the identification-problem, failing to depict Balthasar as a black person would still have significant costs, as it would not only disrupt a tradition with a long history (since the Middle Ages, Balthasar has been represented as a black African king within Spain), ${ }^{47}$ but also one that is valued by many Spaniards.

I believe that two inferences can be drawn from this. One is that, insofar as local black people are willing to play Balthasar in Epiphany parades, they ought to be given this role. Since white people would retain the opportunity to play one of the other two kings (which are roles for which they may need to be prioritised), denying the role of Balthasar to them does not appear unfair. This is true, I submit, even in cases where the three kings are traditionally played by local councillors and where there are no (willing) black councillors to play Balthasar. For even when allowing local councillors to perform these roles role is a way of acknowledging their public service, there will normally be black people among the wider population who have made important contributions to the city or town as well, such that the reasons for denying the role of Balthasar to them do not seem particularly strong. (Accordingly, I take it that Madrid's city council made the right decision in 2015 when, instead of having a nonblack city councillor play Balthasar, it awarded this role to a local black person who was not a city councillor. $)^{48}$

What if there are not any black people among the local population or simply no ones who are willing to play Balthasar, as might be the case in some Spanish villages? Under these conditions, and this bring me to the other implication, it does not seem wrong for blacked-up white locals to do so instead, provided that they do not adopt crude stereotypical features of black people such as overdrawn lips and unrealistically dark skin. As well as making it easier to differentiate the three kings (which again is a sine

44 CNN, "The Black Leaders of an Iconic Mardi Gras Parade Want You to Know Their 'Black Makeup Is NOT Blackface."”

45 CNN

46 Fausset, "A Black Group Says Mardi Gras Blackface Honors Tradition. Others Call It 'Disgusting."”

47 Paul H. D. Kaplan, The Rise of the Black Magus in Western Art, Second edition (Ann Arbor, Mich: UMI Research Press, 1985).

48 Kassam, "Madrid Ends Blacking up of Characters in Post-Christmas Tradition." 
qua non of a parade that revolves around these figures), such cross-racial Balthasar impersonations are necessary under the current conditions for honouring an old and widely valued tradition (see the penultimate paragraph), which suggests that any offence that they may cause would not be gratuitous.

\section{Objections and Some Rejoinders}

My contention hitherto has been that black make-up traditions are morally justified if, but not necessarily only if (more on this in the next section), three conditions are satisfied: (i) the large majority of individuals who help to sustain these traditions do not believe that they denigrate black people; (ii) the relevant traditions do not portray black people in denigrating ways; and (iii) the relevant traditions are not gratuitously offensive. What I want to do in this section is to answer (what I regard as) the most promising objection to the claimed sufficiency of these conditions. This objection maintains that even black make-up traditions that satisfy (i)-(iii) are unjustifiable when, and because, for some local black people, they evoke painful associations with black make-up traditions that are, or were, denigrating to black people (think of the tradition of North American minstrel shows) and/or with other expressions of antiblack racism, whether current or past.

One immediate response here is that, if these associations are triggered because people erroneously believe that the triggering traditions denigrate black people as well, then the most sensible solution would be to alert them to the innocent nature of said traditions rather than to abolish the traditions. Suppose, however, that some black individuals know that a local black make-up tradition is morally innocent (e.g., the New Orleans Zulu parade), but are still painfully reminded by it of racist black make-up traditions. In that case, I still do not think that the tradition ought to be abolished. To see why not, note that, due to the diversity in people's worldviews, religions, cultures, personalities, and experiences, there are numerous public activities that cause some to have painful associations even if they do not necessarily believe that the activities in question are morally problematic. Someone who has been abused by a priest might associate a Catholic procession with child abuse; someone who has gotten injured in a Jihadist attack might associate the wearing of a headscarf with Islamic terrorism; someone whose shop was looted during a BLM riot might associate the wearing of BLM merchandise with looting; someone whose grandfather was a political prisoner in the Soviet Union might associate performances of The Internationale with the Gulags, etc. Were it the case that all of these and many other public activities are unjustified simply because they trigger painful associations among some individuals, then there would remain very few things that we are morally allowed to do in public, which I assume cannot be right.

\section{A Further Case Where Black Make-Up Traditions Might Be Justified}

That concludes my defence of the claim that black make-up traditions can be morally vindicated under certain conditions. I should reiterate at this point that the three conditions that were identified are not necessarily the only ones under which such traditions are justifiable. Consider Saint Nicholas celebrations on the Dutch-Caribbean island of Bonaire where the character of Black Pete has sparked very little, if any, criticism among its predominantly black population, and where Pete impersonators are in fact painted much 
darker than their European-Dutch counterparts. ${ }^{49}$ In the previous section, I have argued that Black Pete portrays black people in a demeaning way given that he has various features that suggest that he is a black servant to a white bishop (Saint Nicholas), who in Bonaire tends to be impersonated by a whitened-up black person. ${ }^{50}$ However, some might say that the fact that most black Bonaireans do not regard Black Pete as morally problematic, along with the fact that a significant proportion of them wants to preserve this character, ${ }^{51}$ is normatively significant. On this view, the pro tanto reasons against Black Pete that stem from his racially denigrating features are outweighed when (I) enough local black people support his presence in Saint Nicholas celebrations and when (II) any opposition to his presence among this group is not too large.

Why think that this view is correct? Those who accept it would argue that respecting people's agency is morally important, and that doing so requires that they have a certain amount of space to present themselves in self-deprecating ways should they wish to do so. (Of course, akin to many people in the European Netherlands, ${ }^{52}$ most Bonaireans might not see Black Pete as belittling black people, which may mean that they do not perceive their support for this character as a form of self-deprecation.) Since an assessment of this argument would take us too far afield, I will not try to evaluate this view here; instead, I will simply point out that, if it turns out to be sound, then the three conditions that I have identified in the penultimate section are not necessary for rendering black make-up traditions morally justified even though they remain jointly sufficient.

\section{Concluding Remarks}

In recent years, it has become common for various specific black make-up traditions, ${ }^{53}$ as well as black make-up traditions in general, ${ }^{54}$ to be denounced as racist. This development fits into a broader trend whereby an ever-expanding set of views, behaviours,

49 Caribisch Netwerk, "Bonaire ziet de klassieke Zwarte Piet als traditie," November 24, 2013, https://caribischnetwerk.ntr.nl/2013/11/24/bonaire-ziet-de-klassieke-zwarte-piet-als-traditie/; Harald Linkils, "Zwarte Piet Polemiek nog steeds aan Bonaire voorbij," Bonaire.Nu (blog), November 5, 2018, https://bonaire.nu/2018/11/04/zwarte-piet-polemiek-nog-steeds-aan-bonaire-voorbij-bomvolsinterklaas-programma/.

50 Janita Monna, "Op Bonaire schminkt de Sint zijn huid elk jaar gewoon wit," Trouw, October 24, 2013, https://www.trouw.nl/gs-ba1cd495; Yamapama, \#FilmpjeVanYaams—Sinterklaas Intocht Op Bonaire, 2019, https://www.youtube.com/watch?v=MjHRk_DmR60feature=youtu.be.

51 See the penultimate footnote.

52 See the penultimate section.

53 For example, the notion that the character of Black Pete is racist has gained much popularity in the Netherlands over the past ten years. See Rozemarijn Lubbe, "Sinterklaas in Coronatijd," 1V Opiniepanel Rapport (EenVandaag, 2020), https://eenvandaag.assets.avrotros.nl/user_upload/PDF/ Rapportage_ZwartePiet_12nov.pdf.

54 See, for instance, a recent panel discussion about the use of black make-up on Al Jazeera; Al Jazeera, "Why Does the Racist Legacy of Blackface Endure?," September 24, 2020, https://www.aljazeera.com/ programmes/thestream/2019/09/25922-200325180725222.html. 
and activities are given this label by predominantly left-leaning individuals, ${ }^{55}$ and not rarely without adequate justification. ${ }^{56}$

My aim here has been to show that, for some contemporary black make-up traditions, accusations of racism are unwarranted. To be more precise, I found that, although there are examples of unjustifiable black make-up traditions such as the Black Pete tradition in the European Netherlands, ${ }^{57}$ there are good grounds for thinking that the New Orleans Zulu tradition is morally justified, as is the use of black make-up in Spanish Epiphany parades when there are no (willing) black locals to perform the role of King Balthasar. My hope is that this article will contribute to more nuanced public debates about these traditions, ones in which people do not take for granted that they are morally indefensible, but where they assess each tradition on the basis of its own characteristics.

Acknowledgments: I thank the two reviewers at this journal, as well as the reviewers at another journal to which an earlier version of this paper was sent, for helpful comments. I am also grateful to the editors for founding this journal.

Funding: My research is supported by an international postdoctoral fellowship (2018-00679) from the Swedish Research Council.

55 See, for instance, Derald Wing Sue et al., "Racial Microaggressions in Everyday Life: Implications for Clinical Practice," The American Psychologist 62, no. 4 (June 2007): 271-86, doi:10.1037/0003-066X.62.4.271. In this influential article, which has been cited over 5000 times according to Google Scholar, racial micro-aggressions include statements such as, "I believe the most qualified person should get the job"; "Everyone can succeed in this society [the US], if they work hard enough"; "There is only one race, the human race"; and "America is a melting pot".

56 Consider, for example, a recent incident in the US where a professor in communication at the University of Southern California was suspended from teaching a course and investigated for discussing a pause-word in Chinese, na ge, that some students believed sounded too much like the N-word. See Kerry Allen, "Investigation into US Professor Sparks Debate over Chinese Word," BBC News, September 10, 2020, sec. China, https://www.bbc.com/news/world-asia-china-54107329.

57 I say the "European Netherlands", for as I suggested in the previous section, the Black Pete tradition might be morally justified in Bonaire, which is part of the Caribbean Netherlands. Whether this is the case is an important topic for future research. 